Received: 16.06.2013; Final Text: 16.01.2014

Keywords: Built environment; living environment; assistive technologies; smart home; the elderly.

\section{AN INNOVATIVE BUILT ENVIRONMENT FORM FOR \\ DWELLINGS FOR THE ELDERLY}

\author{
Bostjan KERBLER*
}

\section{INTRODUCTION}

Europe and the rest of the developed world is increasingly dealing with population ageing. According to the United Nations Department of Economic and Social Affairs (2013), the share of people over sixtyfive increased from 8.2 to $16.2 \%$ between 1950 and 2010, and the ageing rate is expected to increase further in the future. If the natural birth rate continues to decrease and there is no constant (or major) influx of younger people through migration, according to Eurostat's predictions (2011) by 2060 the share of people over sixty-five will represent $29.3 \%$ of the total population in the EU member states, Iceland, Liechtenstein, Norway and Switzerland. Because people will live longer, the demographic structure of the elderly will also change: the number of those over eighty will increase significantly; it is expected to double in the next thirty years, and to almost triple by 2060 . Due to population ageing, and especially due to the rapid increase in the number of elderly and sickly people that usually require a great deal of care, and because families have increasingly more difficulties taking care of their elderly members at home due to the modern tempo and lifestyle, there is increasing pressure to accommodate them in social and healthcare institutions, where they obtain appropriate services. This is creating growing costs for healthcare and social-care systems. This is especially problematic in countries that have largely developed only the institutional form of eldercare, which is the most expensive among all forms of residential eldercare.

The financial sustainability of elderly services is already causing concern, but the European Commission (2007) estimates that in the future the expenditure for pensions, healthcare and long-term care alone will increase by 4 to $8 \%$ of gross domestic product (GDP), and the total costs of healthcare and social-care services are expected to triple by 2050. In 2050, the social-care costs alone are expected to amount to approximately $35 \%$ of GDP in the EU member states (Jespen and Leschke, 2008). Therefore, 


\begin{tabular}{|l|l|l|l|l|l|l|l|l|l|l|l|}
\hline Year/country & $\mathbf{1 9 6 0}$ & $\mathbf{1 9 7 0}$ & $\mathbf{1 9 8 0}$ & $\mathbf{1 9 9 0}$ & $\mathbf{2 0 0 0}$ & $\mathbf{2 0 1 0}$ & $\mathbf{2 0 2 0}$ & $\mathbf{2 0 3 0}$ & $\mathbf{2 0 4 0}$ & $\mathbf{2 0 5 0}$ & $\mathbf{2 0 6 0}$ \\
\hline Bulgaria & 7.4 & 9.4 & 11.8 & 13.0 & 16.2 & 17.5 & 20.9 & 24.2 & 27.4 & 31.1 & 32.7 \\
\hline Czech Republic & 9.5 & 11.9 & 13.6 & 12.5 & 13.8 & 15.2 & 19.6 & 22.0 & 24.8 & 28.7 & 30.7 \\
\hline Germany & 11.5 & 13.5 & 15.7 & 14.9 & 16.2 & 20.7 & 23.0 & 28.1 & 31.7 & 32.3 & 32.8 \\
\hline Estonia & n.a. & 11.7 & 12.5 & 11.6 & 15.0 & 17.1 & 19.1 & 22.3 & 24.8 & 27.7 & 30.5 \\
\hline Greece & n.a. & n.a. & 13.1 & 13.7 & 16.5 & 18.9 & 20.9 & 23.7 & 28.1 & 31.5 & 31.3 \\
\hline Spain & 8.2 & 9.5 & 10.8 & 13.4 & 16.7 & 16.8 & 19.1 & 22.8 & 27.8 & 31.5 & 31.5 \\
\hline Italy & 9.3 & 10.8 & 13.1 & 14.7 & 18.1 & 20.2 & 22.3 & 25.5 & 29.8 & 31.5 & 31.7 \\
\hline Latvia & n.a. & 11.9 & 13.0 & 11.8 & 14.8 & 17.4 & 19.0 & 23.1 & 26.6 & 30.8 & 35.7 \\
\hline Lithuania & n.a. & 10.0 & 11.3 & 10.8 & 13.7 & 16.1 & 17.6 & 22.1 & 25.6 & 27.6 & 31.2 \\
\hline Hungary & 8.9 & 11.5 & 13.5 & 13.2 & 15.0 & 26.6 & 19.7 & 21.8 & 24.8 & 29.2 & 32.1 \\
\hline Malta & n.a. & n.a. & 8.4 & 10.4 & 12.1 & 14.8 & 20.5 & 24.2 & 25.0 & 27.6 & 31.0 \\
\hline Poland & 5.8 & 8.2 & 10.2 & 10.0 & 12.1 & 13.5 & 17.9 & 22.5 & 25.1 & 30.3 & 34.5 \\
\hline Portugal & 7.8 & 9.2 & 11.2 & 13.2 & 16.0 & 17.9 & 20.6 & 24.0 & 27.9 & 31.4 & 32.0 \\
\hline Romania & n.a. & 8.5 & 10.3 & 10.3 & 13.2 & 14.9 & 17.4 & 20.2 & 25.4 & 30.8 & 34.8 \\
\hline Slovenia & n.a. & n.a. & n.a. & 10.6 & 13.9 & 16.5 & 19.8 & 24.2 & 27.5 & 30.6 & 31.6 \\
\hline Slovakia & 6.8 & 9.1 & 10.6 & 10.3 & 11.4 & 12.3 & 16.1 & 20.5 & 24.1 & 29.6 & 33.5 \\
\hline Switzerland & 10.2 & 11.2 & 13.8 & 14.6 & 15.3 & 16.8 & 19.4 & 23.6 & 27.1 & 29.0 & 30.4 \\
\hline EU-27 and other* & 9.6 & 11.0 & 12.5 & 12.9 & 14.5 & 16.0 & 19.1 & 22.6 & 25.6 & 27.8 & 29.3 \\
\hline Japan & 5.7 & 7.0 & 9.0 & 11.9 & 17.2 & 23.0 & 28.6 & 30.7 & 34.5 & 36.5 & 36.9 \\
\hline Republic of Korea & 3.7 & 3.3 & 3.9 & 5.0 & 7.3 & 11.1 & 15.5 & 23.4 & 30.5 & 34.9 & 37.0 \\
\hline Singapore & 2.0 & 3.3 & 4.7 & 5.6 & 7.3 & 9.0 & 13.9 & 20.5 & 25.4 & 28.9 & 32.4 \\
\hline
\end{tabular}

Table 1. Share of people over sixty-five in selected countries.

Note: 1960-2010 (estimated values); 20202060 (projected values); n.a. = not available; $\left({ }^{*}\right)$ = Iceland, Liechtenstein, Norway, Switzerland.

Sources: Eurostat (2013); United Nations Department of Economic and Social Affairs (2013). in the following decades the effect of the post-war baby-boom generation can be expected to show in the provision of eldercare services because this generation will become an increasing user of these services. In terms of the dynamics and especially in terms of the influences on socialhealthcare expenditure or the maintenance of use, the future fluctuation of the dependency ratio, which shows how many elderly are dependent on the working population, is very important. The conditions indicate that there may not be enough working people in the future to support the healthcare and social-care system. By 2060 the old-age-dependency ratio, ratio between the number of workers (fifteen to sixty-four years old) and the number of retirees (over sixty-five) will have fallen from approximately 5:1 in 2000 to 1.9:1 (Eurostat, 2013). In the event of an unchanged rate of growth in the ranks of the older population, an unaltered level of rights in relation to productivity, and unaltered employment rate, the increase in the GDP share of public expenditure connected with ageing is thus the same as the old-age dependency ratio (Dimovski and Žnidaršič, 2007).

Because the financial capacities of countries to maintain the current level and scope of services and institutional care for the elderly are decreasing, there are increasing demands to rationalize the services and residential care of the elderly as much as possible. Since the home assumes the central importance in later life (Heywood et al., 2002) these demands are feasible, considering that the main idea is to enable the elderly to stay in their homes as long as possible, and to move healthcare and social-care services to the homes of the elderly. This involves the concept of ageing in place. The advocates of this idea proceed from elderly people's preferences. Studies show that the elderly wish to stay in their homes and in the same, familiar environment for as long as possible, and to preserve their independence for as long as possible (Callahan, 1992; Rojo Perez et al., 2001; Sabia, 2008; Costa-Font et al., 2009; Wilesa et al., 2009). Even though the preferences 


\begin{tabular}{|c|c|c|c|c|c|c|c|c|c|c|}
\hline Year/country & 2015 & 2020 & 2025 & 2030 & 2035 & 2040 & 2045 & 2050 & 2055 & 2060 \\
\hline Average & 28.5 & 31.4 & 34.6 & 38.3 & 42.3 & 45.5 & 48.0 & 50.2 & 51.8 & 52.6 \\
\hline Belgium & 28.0 & 30.3 & 33.2 & 36.7 & 39.3 & 41.0 & 41.7 & 42.5 & 43.1 & 43.8 \\
\hline Bulgaria & 28.9 & 32.5 & 35.8 & 38.7 & 41.6 & 46.0 & 51.6 & 56.1 & 60.1 & 60.3 \\
\hline Czech Republic & 26.2 & 30.4 & 32.8 & 34.3 & 35.9 & 40.1 & 46.4 & 50.1 & 53.3 & 55.0 \\
\hline Denmark & 28.8 & 31.4 & 33.9 & 37.0 & 40.1 & 41.9 & 42.5 & 41.8 & 42.0 & 43.5 \\
\hline Germany & 32.5 & 35.8 & 40.2 & 47.2 & 54.2 & 56.4 & 56.9 & 58.1 & 59.6 & 59.9 \\
\hline Estonia & 27.2 & 30.7 & 33.1 & 35.8 & 37.6 & 40.5 & 43.6 & 48.3 & 54.3 & 55.5 \\
\hline Ireland & 20.0 & 22.8 & 25.9 & 27.6 & 30.4 & 33.1 & 36.3 & 39.7 & 38.6 & 36.7 \\
\hline Greece & 30.6 & 32.6 & 34.9 & 37.7 & 42.5 & 47.8 & 53.4 & 57.5 & 57.7 & 56.7 \\
\hline Spain & 27.4 & 28.9 & 31.6 & 35.5 & 40.6 & 46.7 & 53.3 & 56.9 & 57.3 & 56.4 \\
\hline France & 29.2 & 32.7 & 35.8 & 39.1 & 42.0 & 44.4 & 44.8 & 45.5 & 46.3 & 46.6 \\
\hline Italy & 33.1 & 34.8 & 37.0 & 41.1 & 46.5 & 51.7 & 55.1 & 56.3 & 56.6 & 56.7 \\
\hline Cyprus & 21.6 & 24.9 & 28.2 & 30.8 & 32.0 & 33.3 & 35.5 & 39.8 & 43.8 & 47.6 \\
\hline Latvia & 26.6 & 28.8 & 32.2 & 36.2 & 39.2 & 43.3 & 47.6 & 54.3 & 63.3 & 68.0 \\
\hline Lithuania & 24.4 & 26.6 & 30.4 & 35.2 & 38.8 & 41.8 & 43.7 & 47.3 & 52.7 & 56.7 \\
\hline Luxembourg & 21.3 & 23.1 & 26.4 & 30.0 & 34.1 & 37.1 & 39.6 & 41.9 & 43.6 & 45.1 \\
\hline Hungary & 26.2 & 30.0 & 32.8 & 33.6 & 35.7 & 39.5 & 46.0 & 50.2 & 54.2 & 57.8 \\
\hline Malta & 27.1 & 31.8 & 36.3 & 39.2 & 39.4 & 40.2 & 42.9 & 46.5 & 51.1 & 55.6 \\
\hline Netherlands & 27.1 & 30.8 & 35.2 & 40.3 & 44.8 & 47.3 & 46.9 & 46.5 & 46.7 & 47.5 \\
\hline Austria & 27.8 & 29.8 & 33.3 & 38.8 & 44.2 & 46.8 & 47.4 & 48.6 & 49.3 & 50.7 \\
\hline Poland & 21.8 & 26.9 & 32.4 & 35.2 & 36.9 & 39.9 & 45.3 & 53.0 & 60.0 & 64.6 \\
\hline Portugal & 29.0 & 31.3 & 34.0 & 37.9 & 41.8 & 46.7 & 52.0 & 55.6 & 56.7 & 57.2 \\
\hline Romania & 22.6 & 25.7 & 29.4 & 30.2 & 35.3 & 40.7 & 47.6 & 53.8 & 62.3 & 64.8 \\
\hline Slovenia & 25.8 & 30.4 & 34.8 & 38.8 & 42.7 & 46.1 & 50.8 & 55.1 & 57.8 & 57.6 \\
\hline Slovakia & 19.1 & 23.6 & 28.0 & 31.4 & 33.9 & 38.0 & 44.6 & 51.4 & 57.6 & 61.8 \\
\hline Finland & 31.4 & 36.2 & 39.8 & 42.7 & 44.3 & 43.5 & 43.8 & 44.9 & 45.7 & 47.4 \\
\hline Sweden & 31.3 & 33.5 & 35.3 & 37.2 & 39.3 & 40.5 & 40.9 & 41.7 & 43.7 & 46.2 \\
\hline United Kingdom & 27.8 & 29.6 & 31.7 & 34.8 & 37.7 & 38.9 & 38.6 & 39.4 & 40.9 & 42.1 \\
\hline Iceland & 21.3 & 25.7 & 28.8 & 32.2 & 33.9 & 34.5 & 34.0 & 33.5 & 32.6 & 33.5 \\
\hline Liechtenstein & 24.2 & 29.7 & 36.2 & 43.6 & 50.6 & 54.4 & 54.6 & 54.1 & 53.5 & 52.9 \\
\hline Norway & 25.0 & 27.4 & 30.3 & 33.0 & 36.1 & 38.5 & 39.4 & 40.3 & 41.5 & 43.0 \\
\hline Switzerland & 27.0 & 29.5 & 33.1 & 38.0 & 42.8 & 45.7 & 48.0 & 50.5 & 52.8 & 54.4 \\
\hline
\end{tabular}

Table 2. Projected old-age dependency ratio in EU member states, Iceland, Liechtenstein, Norway and Switzerland.

Note: Average = EU member states, Iceland, Liechtenstein, Norway and Switzerland.

Source: Eurostat (2013). of the elderly depend on cultural differences, in most places the elderly see institutionalisation as a very traumatic experience and mostly have a negative attitude towards it. It is often the last resort, and many times they consider it to be their final refuge before death. Such a mentality is more deeply rooted in societies where there is no diversity in institutions and group housing for the elderly. Avoiding institutional care as long as possible is therefore in the interest of the elderly and it is also in the public interest because it tends to limit the demand for institutional care only to people that really need this form of social assistance.

The idea of moving healthcare and social-care services into the homes of the elderly can be carried out by appropriately adapting the infrastructure and the built environment. A good basis for this is offered by modern technologies that can be used to convert an elderly person's home into an innovative living environment. This article presents such an environment offering support to the elderly, and discusses its importance and functioning, the efforts and achievements made to date in developing this innovation, and the premises for implementing it in practice based 
on elderly people's opinions about living in these advanced living environments. The article is based on an analysis of relevant scholarly literature and studies on the topic as well as on our own research results and offers new findings, syntheses, ideas and (critical) views, while also raising questions for further consideration and providing premises for future research and applied work in this area.

\section{THE CONCEPT OF AN INNOVATIVE BUILT LIVING ENVIRONMENT}

\section{Gerontechnology and assistive technologies}

The development of modern technologies and population ageing are parallel and interconnected processes in developed countries; modern diagnostics and treatment methods are used to prolong life, and modern technologies offer life and residential assistance to the elderly. Due to this interconnection, new interdisciplinary areas such as gerontechnology and domotics have even developed. The former is a combination of "gerontology", the science of ageing and age, and "technology". According to Fozard et al. (2000) the term was coined by Graafmans and Brouwers in 1989. It studies and develops technologies that are based on scholarly findings about the ageing process, and its goal is to improve health and facilitate the everyday lives of the elderly, and to enable them to live independently and participate in society (Fozard et al. 2000; Harrington and Harrington, 2000; Bouma et al., 2007). Domotics is derived from the Latin word domus "home" and the English word "informatics". It studies the application of information technologies that can be built into the living environment (Demiris and Hensel, 2008). In terms of the development of technology for the elderly, one can roughly define two directions (Rudel et al., 1993): improving and developing assistive technologies that make elderly persons' daily lives in their living environment easier, and developing and spreading information technology that exceeds the limitations of physical space through telecommunications.

The term "assistive technologies" denotes any device, equipment, product or tool that enhances, preserves or improves the functional abilities of the disabled, who can use it to more easily and safely perform a specific task that they otherwise could not perform (see, e.g., Cowan and TurnerSmith, 1999; Cavanaugh, 2002; Edyburn, 2004). According to Barlow and Venables (2004), assistive technologies make it possible for the user to more effectively control the environment with as little physical effort as possible, in which, as highlighted by Heywood (2004), planning assistive technologies and integrating them into the living environment should take into account not only general standards, but also individuals' specific needs. Assistive technologies thus reduce the differences between an individual's abilities and the environment, which enables independent life in the living environment (McCreadie and Tinker, 2005). A distinction is made between low-, mid-, and high-level assistive technologies (Kaye et al., 2008). The first include minor mechanical changes or adjustments in a specific type of product (e.g., furniture), the second include simple aids that, in contrast to the first, require a source of energy to work (e.g., automatic alerts) and the third involve programmed devices with built-in electronics (Cavanaugh, 2002).

\section{Smart home and its importance}

The development of modern information and communications technology (ICT) opens new opportunities and solutions for assistive technologies. 
Together with computer hardware and software, ICT makes it possible to control and manage assistive technologies in the home. This reduces physical distance and expands the social dimension of space (Hojnik-Zupanc, 1999). The concept is known as an ambient intelligence or a smart environment. According to Remagnino and Shapio (2007), these terms are used to identify methodologies and technologies that provide an environment that responds effectively to a user's needs. Such an environment combines computer and advanced network and assistive technologies (smart and innovative devices), and special interfaces (sensors) that perceive and interact with users in a discrete manner. The hardware must be integrated into the environment in a non-intrusive manner and in minimal dimensions, with the smallest possible use of space and energy, which is made possible by smart materials, various nano-technologies and so on. The complex heterogeneous network (i.e., the telecommunications infrastructure) operates discretely in such environments. These environments recognize the presence of persons in a room based on physiological characteristics (e.g., voice and gestures) and are always ready to respond to a request for ambient assisted living. This enables the system to control what is going on in the environment and monitor the user's biological functions as well as his or her safety. The operation of the ambient intelligence is supervised, which ensures safety in terms of technologies and ethics (e.g., safety of the user's biometric and other personal data; Rodriguez et al., 2005; Zupan et al., 2007). A smart home is an ambient intelligence application that is an example of an innovatively built living environment.

A smart home is a system that responds to people's needs and activities, and is adapted to their cognitive and physical abilities (Pecora and Cesta, 2007). Such homes are outfitted with state-of-the-art equipment, tools and technology, which are functionally interconnected. The electronic systems in smart homes monitor the living environment and can even perform certain tasks (opening and closing doors, raising blinds, and turning the heating on and off) with minimum physical force using various methods (remote control, voice command, a control panel on a wheelchair and even by moving the eyes). These homes have builtin communications technology that enables electronic access to and inclusion in various environments: the built environment in the form of buildings and social infrastructure, the social environment (interaction with the family, neighbours and service providers), and the secondary environment (culture, politics, business, ecology and so on; Zupan et al. 2007). Emiliani and Stephanidis (2005) believe that these systems define the vision of the information society and that in the future they will provide support to a wide range of electronically transmitted human activities and access to a number of services and applications, especially because technologies are becoming increasingly cheaper and the availability of various telecommunications types is also increasing. Therefore, smart home technologies can support the health, safety and independence of the elderly. "While these technologies offer significant benefits to older people and their families, they are also transforming older adults into lead adopters of a new 24/7 lifestyle of being monitored, managed, and, at times, motivated, to maintain their health and wellness" (Coughlin, 2007, 1810). However, even with the best technical and technological support, smart homes cannot serve their purpose on their own if the living environment is not physically adapted from the very start: it must be without any architectural barriers and adapted to elderly people's needs, abilities and 
demands. In adapting the physical living space in a smart home, one needs to follow the principles of inclusive design (Imrie and Hall, 2001) or design for all (Goodall and Pottinger, 2010), also referred to as universal design (Mace, 1998; Danford and Tauke, 2001; Erk1lıç, 2011). Principles of such design are as follows (Mace, 1998; Iwarsson in Stahl, 2003):

- equitable use - the design should provide the same means of use for all users,

- flexibility in use - the design should accommodate wide range of individual preferences and abilities,

- simple and intuitive - use of the design should be easy to understand, regardless of the user's experience, knowledge, language skills, or current concentration level,

- perceptible information - different modes (pictorial, verbal, tactile) for redundant presentation of essential information should be used,

- tolerance for error - the design should minimize hazards and the adverse consequences of accidental or unintended actions,

- low physical effort - the design should be used efficiently and comfortably and with a minimum of fatigue,

- size and space for approach and use - appropriate size and space should be provided for approach, reach, manipulation, and use regardless of user's body size, posture, or mobility.

These principles emphasize the accessibility of the built living environment, in which its layout must be as functional as possible and user-friendly, which means that it does not unnecessarily complicate the use of the built environment, objects and products, but meanwhile it preserves their aesthetic and practical value (Kervina et al., 2007). Some examples: the passages between the rooms must be without thresholds, the floor must be level and not slippery, the doors and halls must be wide, the furniture, electrical installations and windows must be at an appropriate height, bathrooms must have handles, seats, backrests and adapted furniture, and the rooms must have adequate lighting, a proper contrast between bright and dark colours, and so on. Smart homes are thus a combination of the living environment without architectural barriers and the assistive information communications technologies built into this environment. The built environment in a smart home should be accessible to everyone.

\section{RESEARCH AND ACHIEVEMENTS IN INNOVATIVE BUILT LIVING ENVIRONMENTS FOR THE ELDERLY}

In Europe (e.g., in Scandinavia, the Netherlands, the UK, Germany, Italy, and France) and elsewhere (e.g., the U.S., Japan, South Korea, and Singapore), numerous test projects and applied projects are taking place in innovative built living environments for the elderly. The majority of research refers to the idea of moving healthcare and social-care services to the home environments of the elderly, and to the issue of how to most effectively link the smart-home environments of the elderly to a "remote control" network, which provides remote access to care and other healthcare services. The first, simpler versions of these systems were developed in some western European countries more than twenty years ago. These were safety alarm systems that consisted of a simple telephone- 


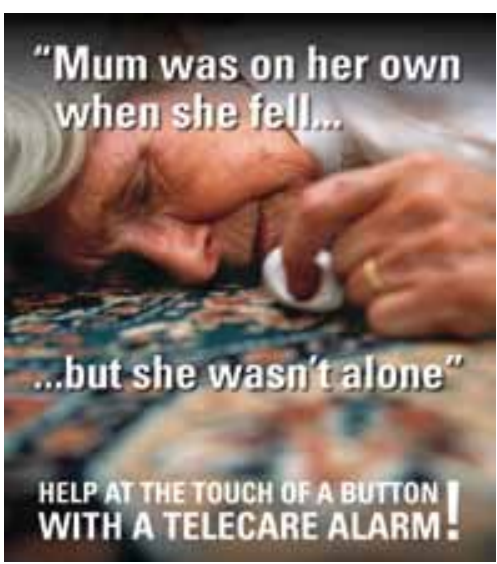

Figure 1. A wireless remote activator - the first generation of the safety alarm systems (Surrey Telecare, 2013). based device. Users had a special telephone with a wireless remote activator that they carried on themselves (such as a bracelet or a pendant). This control/communications platform enabled users to trigger a wireless activator at anytime and anywhere in the apartment or house (even when they could not reach the phone) to call a caretaker (a relative, neighbour or friend) or control centre for assistance and discuss possible ways to receive help (Miskelly, 2001). The service could also include a reminder function that sent reminders to the user at a specific time to perform a specific task. The reminders were sent to one or several addresses at the same time, including to the user's caretaker. The users had to confirm that they received the reminder. If they did not confirm it, the reminder was sent again and the caretaker was notified (Cimerman et al., 2010). These simple versions of the safety alarm system are intended for elderly people with various health problems such as forgetfulness and various forms of disability (Ocepek and Zupan, 2008).

The extent of usage differs and varies from one country to another. The ICT and Ageing - European Study on Users, Markets and Technologies (Kubitschke and Cullen, 2010) showed that the share of users over 65 is the highest in the UK and Ireland (14-16\%), followed by Sweden, Finland and Denmark (6-10\%), and the U.S., Spain, Germany, Hungary, the Netherlands, Italy, France and Japan (1-3\%). There are several providers of advanced ICT-systems in the U.S. that collect information on vital functions in the home and send it to special healthcare and other assistance centres though home networks and broadband communication paths. Currently, the UK is at the forefront in implementing these forms of ambient intelligence. The British government defined such implementation into society as one of the most important national strategic development priorities. According to Barlow and Hendy (2009), £175 million was allocated between 2006 and 2011 to carrying out pilot projects in England, Wales, Scotland and Northern Ireland in order to obtain as much practical experience and evidence as possible based on which smart homes could be implemented successfully and with a higher certainty. The results are very encouraging. For example, in Scotland six pounds was saved for each pound invested in establishing, developing and implementing the system ( $£ 8$ million was invested and $£ 48.4$ million saved; see Joint Improvement Team, 2010). Specifically, this included $47.5 \%$ thanks to reducing the number of admissions to care institutions, $42 \%$ by reducing the number of unnecessary hospital stays (due to faster discharge), $9.1 \%$ by reducing unexpected hospital admissions (due to the system's fast responsiveness to injuries in the home) and reducing the number of night shifts and home calls. Telecare is used with these kinds of advanced smart-home systems for the elderly.

Advanced systems of the innovative built living environment operate such that sensors discretely built into the user's home (smart) environment (e.g., on doorknobs, handles and watches) monitor the user's life cycle: a) they measure the user's physiological functions (heartbeat, blood pressure, skin moisture, blood sugar levels, body weight, temperature, percentage of carbon dioxide in exhaled air, body noises, urine and stool, and so on); b) they monitor the user's activity (e.g., slow and permanent changes in his or her lifestyle, and they evaluate the behaviour patterns of those monitored based on the number of times they go through the door, open the refrigerator, and step on the rug by the bed, and based on when they eat and how many meals they have); and c) they remind and warn users with cognitive or sensory deficiencies (e.g., when to take medications, and 
they give voice instructions on how to do things in a room). In addition to these devices, which monitor the user's condition, a smart home also contains built-in devices that identify any unusual state or conditions in the living environment and thus ensure safety and supervision; these include movement detectors (for detecting falls, automatically turning the lights on and off, and opening the door), and fire, smoke, gas and water detectors. All of the information is transferred to and recorded in a remote information (control) system. If this system detects any changes that deviate from the user's normal parameters or the condition of his or her living environment, it sets off an automatic alarm that is transferred to the call (alarm) centre (the remote caretaker), which takes the necessary steps in the user's home. Barlow et al. (2006) thus define this system as a "response mode" or "r-mode." The telecommunications alarm centre can serve as an information-coordination centre and play the role of a mediator between users and assistance providers (like the protection-alarm system). It can also perform a combined role of an information-coordination centre and a service-provider mediator, and also include assistance providers in its operations; for example, community nurses, social workers, emergency medical service, fire-fighters, relatives, neighbours and so on. Based on the type and gravity of the problem(s), the person in charge at the call centre provides suitable instructions (recommendations) to the user (e.g., to take medications or visit a doctor) or informs a public service or service provider of the user's needs (Rudel, 2007). The call centre's operation is also supported by a medical team that has occasional remote access to the data stored in the clinical information database. The detection of various biophysical patterns provides important information for the early detection of a deteriorated health status in an individual and can contribute to suitable adjustment of the treatment program or help alleviate any chronic conditions. In addition, this information not only makes it possible to automate routines, but also provides better and more informed insight into

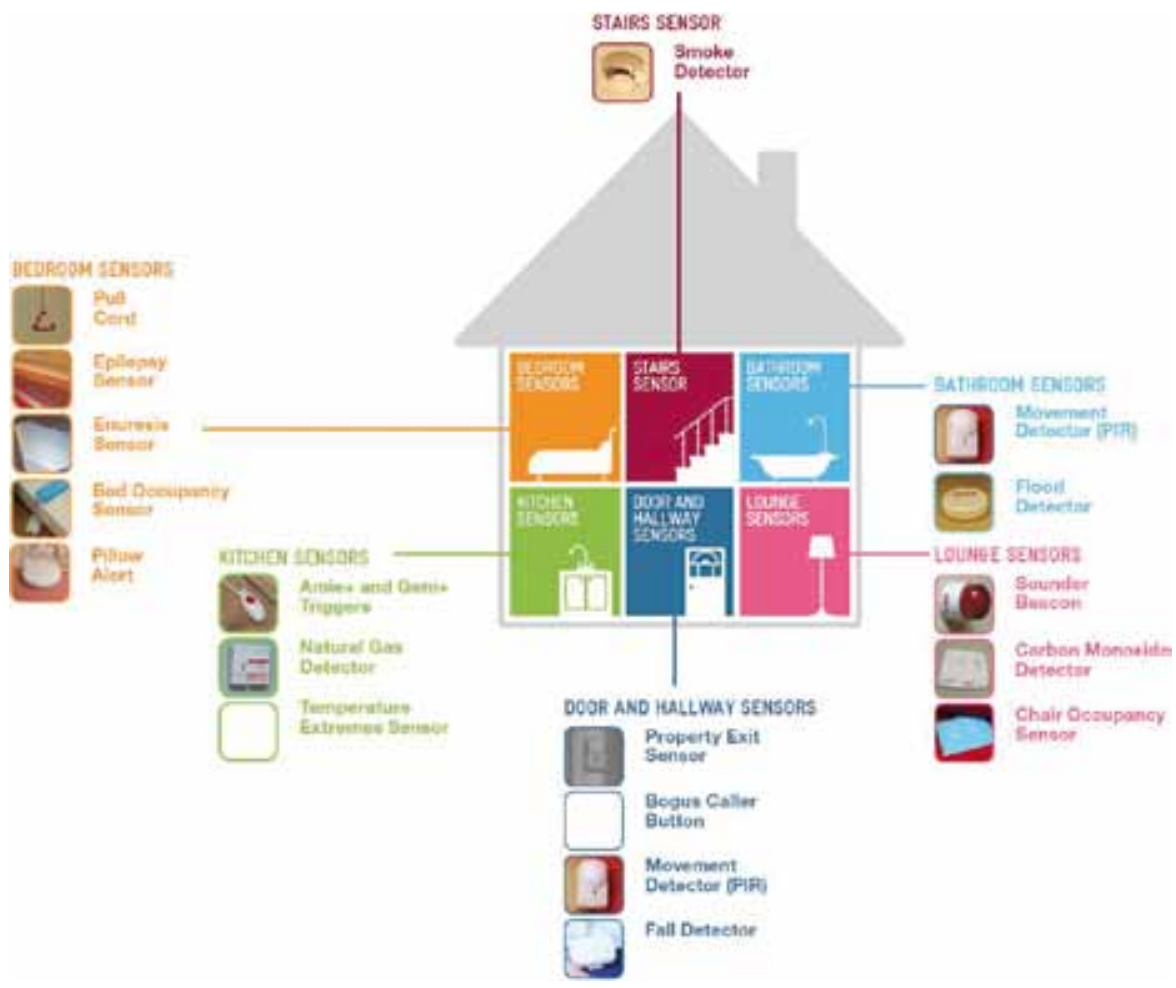


the condition and understanding of the patients' needs. Users that wish to monitor the results of their health efforts can access their aggregated data outfitted with appropriate recommendations and advice any time through the ICT. In this way they can actively and effectively participate in promoting health, care, and remote protection (Jelenc, 2007). Barlow et al. (2006) define this type of system as a "preventive mode" or "p-mode." Recently, an even more innovative form of built living environment has been developed that focuses on the quality of users' lives rather than on their independence and safety. With these systems, users can access virtual media and the Internet to participate in the wider social environment (video connections to maintain contact with relatives and friends, and to virtually participate in group activities). This type of smart-home system is called a "virtual neighbourhood" because users can use it to perform services and socialize with other people without having to leave their homes (Brownsell et al., 2008, 2011); this prevents them from feeling alone and isolated.

\section{DEFICIENCIES OF PROJECTS TO DATE AND PROPOSALS FOR IMPLEMENTING INNOVATIVE BUILT LIVING ENVIRONMENTS FOR THE ELDERLY IN SOCIETY}

Despite successful pilot and test projects, advanced forms of an innovative built living environment for the elderly are not yet widely implemented. Their main purpose is often overly unilateral because they largely study the effects of smart homes on people's health and the operation of the technologies used; this is confirmed by the analysis of research publications from 2005 to 2013 that was conducted for this purpose. By entering the search string "smart home" in international bibliographical databases such as Ebscohost, ProQuest, ScienceDirect, Springerlink, and Thomson Reuters ISI Web of Knowledge, 924 research articles were found, among which $81 \%$ presented and evaluated clinical results or presented studies in which smart-home devices were tested. A more detailed analysis shows that these studies largely tested and analyzed those parts of the innovative built living environment systems and their devices that provide safety and control, detect users' activities, measure their physiological functions and transmit reminders; only $17 \%$ of the studies examined the devices that enable and record users' social interactions. The same research, but on a wider sample, was done by Demiris and Hensel (2008). To cover not only the medical but also the social sciences and electronics literature, the authors conducted extensive searches across disciplines (e.g., Medline, Embase, CINAHL, PsycINFO, Electronics and Communications Abstracts, Web of Science etc.). In order to be inclusive of all new initiatives and efforts in this area given the innovativeness of the concept, they manually searched for relevant references in the retrieved articles as well as published books on smart homes and gerontechnology. The authors report that most of the identified studies demonstrate the feasibility of the technological solution or preliminary evaluation approaches with a limited number of subjects either in a laboratory setting or limited community based settings: $71 \%$ include technologies for functional monitoring, $67 \%$ for safety monitoring, $47 \%$ for physiological monitoring, $43 \%$ for cognitive support or sensory aids, $19 \%$ for monitoring security and only 19\% to increase social interaction.

Based on this results it can be concluded that the studies of smart-home concepts largely focus on ways to promote health and to a much lesser 
degree on ensuring quality living, even though the social importance of smart homes has already been emphasized by Moran (1993):

"Introducing advanced technologies to homes can change the quality aspects of living, and relations between the household members, as well as the social role and function of the home and its connection with the wider environment ... These technologies have important consequences not only for our health, but also and especially on our quality of life." (Moran, 1993, 15)

Twenty years later, the process of developing and implementing innovative built living environments takes place more or less because of the need to rationalize healthcare and social-care services, but far too little attention is paid to users and their wishes and needs. According to Forlizzio et al. (2004) many of assistive products have been designed with little consideration of the social, aesthetic, and emotional relations that the elderly will form with the product. We believe this is wrong. "As technological advances enable sophisticated homebased solutions, we need to ensure that the design and implementation of informatics applications for older adults are not determined simply by technological advances but by the actual needs of end users" (Demiris and Hensel, 2008, 40).

Technologies form the basis for the operation of smart-home systems, but any innovation can only be successfully implemented if the abilities offered by the new technology match users' needs, demands and capabilities. According to Rogers (1962) and a number of authors after him (e.g., Smixmith and Smixmith, 2000; Levy et al., 2003; Demiris et al., 2004; Hanson and Percival, 2006), not paying attention to user needs in particular turned out to be one of the major factors hindering the implementation of innovations. Users are not interested in the technological aspects of the innovation, but primarily in its applicability, and therefore successfully implementing innovative living environments for the elderly also depends on how this concept is accepted by users. Thus the service or the "service experience" is what they are interested in rather than the devices and systems in and of themselves. The main question is thus what users like and what "works" for them (Saranummi et al., 2006). Research on the innovative built living environment and its implementation in society should therefore focus more on users. Users should evaluate the features and effects of living in such an environment based on how they perceive and understand it (as a desired or undesired form of living). Based on a sufficiently large number of these types of studies (and subsequent user experiences), the user perceptions could be generalized and this could be of great help to technology and smart-environment developers, which would likely increase the success rate of putting innovative built living environments into practice. However, in order for users to realistically evaluate the technologies, the main goal of the implementation process should be assigning meaning to and understanding the concept of an innovative built living environment. User perceptions can be distorted for various reasons, which is especially relevant for innovations based on the most advanced forms of ICT and intended for the elderly. Studies (see Hanson 2001; Marquié et al., 2002; Richardson et al., 2005; Lee and Phippen, 2006; Richardson, 2006) show that elderly people generally do not trust ICT. Tetley et al. (2001) report that one of the most common dissuading beliefs among the elderly is that living in an intelligent environment is overly automated or that they perceive technology as a substitute for a personal form of care, protection and communication, which could result in reduced social interaction and isolation or, as Wyde and Valins (1996) point 
out, in creating a society of "high-tech hermits." According to Sponselee et al. (2008), this means that the elderly suffer from "technophobia"; they are afraid of innovation and new technologies. Pečjak (1998) believes this is because they do not know how to use these technologies, and Czaja et al. (2006) believe this is because they do not have confidence in and doubt their own abilities due to sensory and cognitive deficiencies. Cheverst et al. (2003) justify this by the fact that the elderly are more conservative and do not want their lives and life habits to change too much, especially not due to external, less known or alien factors that may interfere with their privacy. Fisk (2003) and Percival and Hanson (2006) believe that especially with regard to advanced systems of innovative built living environments the elderly are afraid of losing their privacy because they have the unpleasant feeling of being constantly watched (Big Brother syndrome), which is also confirmed by studies conducted by Redford and Whitten (1997), Glueckauf and Ketterson (2004) and Bertera et al. (2007).

The results of our research conducted in 2012 show the importance of (correctly) informing potential users and raising their awareness and understanding of the operation and usefulness of an innovative built living environment for the elderly. The data were collected using face-toface interviews and the research sample included people over sixty. They were divided into two groups with 57 participants in each group. Before the interviews, the smart home, its operation and how one can live in it were briefly presented to the first group. The concept of an innovative built living environment was explained more thoroughly to the second group before the interviews, but still in a simple and understandable way. Five short "scenarios" were prepared in advance to show how the system works, how it can be used and what the role of users in relation to technologies is like in such a living environment, using everyday events from the life of the elderly. In this way the respondents were able to imagine what it was like to live in this environment and they could ask the researchers further questions after the presentation. Based on how the respondents had been informed, the difference in the opinions of the first and second groups was quite obvious. In the first group, the respondents had a notably negative attitude towards smart homes and living in them, whereas in the second group they had a positive opinion of it: a full $78.4 \%$ of them replied they would be willing to live in a home living environment that would provide telecare using modern technologies. The importance of assigning meaning to and understanding the concept of an innovative built living environment for successful implementation is also confirmed by the results of attempts to implement these environments in Scotland. From 2007 to 2010, 25\% of new users there (compared to the initial state) decided to integrate smart technologies into their home environment and integrate their homes into the remote control network and thus connect them with care and other service providers. This confirms that they were well informed because the Scottish government dedicated special attention to this project (see Joint Improvement Team, 2010). In this it turned out that user experience had an important effect on raising awareness and understanding, and the subsequent acceptance of this innovation. As reported by Beale et al. (2010), the data on user satisfaction, which were made available to potential users in Scotland, were obviously sufficiently persuasive to motivate a wide circle of addressees: $60.5 \%$ of users believed that their quality of life improved through the reorganization of their homes into a smart environment and their inclusion in the remote care and protection system; $93.3 \%$ of users believed this made them safer, $69.7 \%$ 
thought they were more independent and $87.2 \%$ reported that other family members had less work with them. Such positive experiences are extremely useful for promoting innovations and increasing trust in the concept of innovative built living environments in society, and thus also for their successful implementation.

However, disseminating information and raising people's awareness should not be limited only to the elderly as the users, but it should also include formal and informal caretakers - that is, the target audience that ultimately makes up the market for innovative built living environments. According to the results of Seniorwatch (European Commission, 2008), more than $80 \%$ of the elderly are assisted in their daily activities and tasks by one of their family members as informal caretakers and care providers. The statements of relatives reported by Beale et al. (2010) also confirm that these new technologies can also help caretakers: $74.3 \%$ of relatives felt less burdened thanks to their use. In the future it would thus make sense to also include relatives in this study because their views also have an important effect on how telecare is accepted, supported and used in society. However, in order to realistically evaluate it, the remote home care system should also be appropriately presented to them and assigned proper meaning because, as the results of other studies show, the views of caretakers can also often be distorted due to various reasons. Perceptions connected with telecare that may be present among the caretakers include fear or resistance to the service and excessive excitement over it. They primarily resist the service because ICT-assisted care of the elderly seems impersonal to them and also because, as Raappana et al. (2007) report, they are afraid they would have to (partially or fully) give up their role of caretakers, which formal caretakers in particular feel called to do. According to researchers, this fear often results from the fact that caretakers have insufficient knowledge of the use of these technologies and regard training as an additional, unnecessary and stressful obligation. Thus, if caretakers understood how these technologies work, got to know their advantages and benefits and learned how to use them, the fear would be gone and they would therefore also accept them as part of their lives and work. In addition to resisting these technologies, caretakers can also be overly excited about them, which also prevents objective evaluation of the concept of a smart home and keeps it from being successfully implemented. Raappana et al. (2007) report that these perceptions of innovative built living environments can most often be ascribed to informal caretakers (i.e., relatives). The modern tempo and way of life increasingly limits the opportunities for family home care of elderly family members.

"It seems that in Europe in recent years the main provider of eldercare to date (i.e., the family) has been failing to perform this role" (Ministry of Labour, Family and Social Affairs, 2007, 9).

Therefore, family caretakers expect innovative ICT to replace or completely disburden them, which is a utopia and dangerous both to the elderly, who might actually become socially isolated, and to successfully implementing the concept of smart homes because the disappointment following the realization that ultimately technology cannot replace people might lead to resistance and spreading negative views of this innovation. Therefore home caretakers should be informed in detail what the actual capabilities of technologies in innovative built living environments are and have realistic expectations about them. 


\section{CONCLUSION}

Innovative built living environments provide a way of realizing the idea of moving social-care and healthcare services to the homes of the elderly and thus rationalizing the increasing public expenditure due to population ageing. It can be expected that these living environments will gradually become part of elderly people's daily lives in the future; this will be greatly influenced by society itself because it is increasingly turning into an information society, in which assistive technologies and ICT are increasingly being accepted as part of people's daily lives. However, due to population ageing and the subsequent increasing cost pressure on the healthcare and social-care systems, an overly timeconsuming and spontaneous implementation of innovative built living environments would be detrimental to society. Equally detrimental would be inadequately planned, overly unilateral and overly fast implementation arising only from the need to achieve financial sustainability and due to technological development, and not taking place in line with the needs, wishes and concepts of society, especially, as it has turned out, those of the future users of innovative built living environments and related services. Implementation must therefore follow a model that enables users to be active and central participants in this process. The elderly should come to the realization that these living environments make it possible for them to remain in their homes or the same, familiar environments longer and retain their independence. On the other hand, caretakers must realize that these technologies will not replace them or that they cannot be replaced by them, but that they can disburden them. This is a participatory evaluation approach that can help users in their efforts to achieve the goals set, and to develop and empower themselves. Of course the highlighted user aspect of the implementation does not guarantee that the concept of an innovative built living environment would be automatically accepted and generally established in society. It is an important basis for this, especially for promoting this idea in society, but the entire process of implementing this concept demands a combination of technological and organizational planning, and also includes other stakeholders (i.e., buyers of or payers for the care service such as insurance companies, municipalities and the state, remote control system providers such as telecommunications alarm centres, and developers of technologies and infrastructure) in addition to users. These stakeholders have different risk perceptions and value systems that need to be addressed. Further research in this area should therefore take these findings into account and also evaluate other conditions and demands of various stakeholders (not only the elderly), which means that quick changes in implementing the concept of innovative built living environments in society are not to be expected. In the future also more detailed research on deficiencies of projects to date for implementing innovative built living environments for the elderly in society should be conducted (with case studies etc.). But, however, a major step would already be made if elderly people's homes started to be converted based on the principles of design for all and if architectural barriers in them were removed and new homes were built without these barriers. This would make it possible for the elderly to remain in their home environments longer, while also serving as a basis for changing these environments into smart homes by building assistive technologies and ICT into them. 


\section{ACKNOWLEDGMENTS}

This article is based on the study which was financed by the National Research Agency. I would like to thank my colleagues on the International Forum Ambient Assisted Living for all of their valuable advice and assistance.

\section{BIBLIOGRAPHY}

BARLOW, J., BAYER, S., CURRY, R. (2006) Implementing complex innovations in fluid multi-stakeholder environments: Experiences of telecare, Technovation (26) 396-406.

BARLOW, J., HENDY, J. (2009) The challenges of adopting integrated mainstream telecare services: Lessons from the UK, Eurohealth (15) 8-10.

BARLOW, J., VENABLES, T. (2004) Will technological innovation create the true lifetime home?, Housing Studies (19) 795-810.

BEALE, S., TRUMAN, P., SANDERSON, D., KRUGER, J. (2010) The initial evaluation of the Scottish telecare development program, Journal of Technology in Human Services (28) 60-73.

BERTERA, E.M., TRAN, B.Q., WUERTZ, E.W. BONNER, A.A (2007) Attitudes towards health technologies for telecare and their relationship to successful aging in a community-based older minority population, Forum on Public Policy: A Journal of the Oxford Round Table 1-22.

BOUMA, H., FOZARD, J.L., BOUWHUIS, D.G., TAIPALE, V.T. (2007) Gerontechnology in perspective, Gerontechnology (6) 190-216.

BROWNSELL, S., BLACKBURN, S., HAWLEY, M. (2008) An evaluation of second and third generation telecare services in older people's housing, Journal of Telemedicine and Telecare (14) 8-12.

BROWNSELL, S., BRADLEY, D., BLACKBURN, S., CARDINAUX, F., HAWLEY, M.S. (2011) A systematic review of lifestyle monitoring technologies, Journal of Telemedicine and Telecare (17) 185-189.

CALLAHAN, J. (1992) Aging in Place. Generations (16) 5-6.

CAVANAUGH, T. (2002) The need for assistive technology in educational technology, AACE Journal (10) 27-31.

Chester \& District Housing Trust (2013) ChesterCare service, [http://www. cdht.net] (22.11.2013).

CHEVERST, K., CLARKE, K., DEWSBURY, G., HEMMINGS, T., HUGHES, J., ROUNCEFIELD, M. (2003) Design with care: Technology, disability and the home, Inside the smart home, ed. R. Harper, Springer, London; 163-179.

CIMERMAN, P., BORŠTNAR, T., RUDEL, D., OBREŽAN, D. (2010) E-reminder for selfhealth care - presentation of a solution, Informática Medica Slovenica (15) 51-52.

COSTA-FONT, J., MASCARILLA-MIRÓ, O., ELVIRA, D. (2009) Ageing in place? An examination of elderly people housing preferences in Spain, Urban Studies (46) 295-316.

COUGHLIN, J. F, D'AMBROSIO, L. A, REIMER, B. (2007) Older adult perceptions of smart home technologies: Implications for research, 
policy and market innovations in healthcare, Annual International Conference of the IEEE Engineering in Medicine and Biology Society, Lyon, 1810-1815.

COWAN, D., TURNER-SMITH, A. (1999) The role of assistive technology in alternative models of care for older people, Royal commission on long term care, ed. A. Tinker, King's College London, London; 325-346.

CZAJA, S., CHARNESS, N., FISK, A., HERTZOG, C., NAIR, S., ROGERS, W., SHARIT, J. (2006) Factors predicting the use of technology: Finding from the Center for research and education on aging and technology enhancement (CREATE), Psychology and Aging (21) 333352.

DANFORD, G. S., TAUKE, B., eds. (2001) Universal Design New York. Vanguard Direct, New York.

DEMIRIS, G., HENSEL, B.K. (2008) Technologies for an aging society: A systematic review of "smart home" applications, IMIA Yearbook of Medical Informatics; 33-40.

DEMIRIS, G., RANTZ, M., AUD, M., MAREK, K., TYRER, H. (2004) Older adults' attitudes towards and perceptions of 'smart home' technologies: A pilot study, Medical Informatics and the Internet in Medicine (29) 87-94.

DIMOVSKI, V., ŽNIDARŠIČ, J., (2007) Economic aspects of population ageing in Slovenia: How to mitigate the consequences with the approach of active ageing, Kakovostna starost (10) 2-15.

EDYBURN, D.L. (2004) Rethinking assistive technology, Special Education Technology Practice (5) 16-23.

EMILIANI, P.L., STEPHANIDIS, C. (2005) Universal access to ambient intelligence environments: opportunities and challenges for people with disabilities, IBM System Journal, Special issue on Accessibility (44) 605-619.

ERKILIÇ, M. (2011) Conceptual challenges between universal design and disability in relation to the body, impairment, and the environment where does the issue of disability stand in the philosophy of UD?, METU JFA (28) 181-203.

EUROPEAN COMMISSION (2007) Ageing well in the information society. An i2010 initiative action plan on information and communication technologies and ageing, publication no. COM(2007) 332 final, Brussels.

EUROPEAN COMMISSION (2008) Seniorwatch 2: Assessment of the senior market for ICT progress and developments, publication no. SMART 2006/0062, Information Society and Media Directorate General, Brussels.

Eurostat (2013) Europop2010: Poulation projections. [http://epp.eurostat. ec.europa.eu/statistics_explained/index.php/Population_projections] (10.06.2013).

FISK, M. (2003) Social alarms to telecare: Older people's services in transition, Policy Press at the University of Bristol, Bristol.

FORLIZZI J., DISALVO C., GEMPERLE F. (2004) Assistive Robotics and Ecology of Elders Living Independently in Their Homes. HumanComputer Interaction (19) 25-59. 
FOZARD J. L, RIETSEMA J., BOUMA, H., GRAAFMANS J. A. M. (2000) Gerontechnology: Creating Enabling Environments for the Challenges and Opportunities of Aging. Educational Gerontology, (26) 331-344.

GLUECKAUF, R.L., KETTERSON, T.U. (2004) Telehealth interventions for individuals with chronic illness: Research review and implications for practice, Professional Psychology: Research and Practice (35) 615-627.

GOODALL, B., POTTINGER, K.G. (2010) Promoting inclusive access to the built environment, College of Estate Management, Reading.

HANSON, V.L. (2001) Web access for elderly citizens, IBM T.J. Watson Research Center, Hawthorne.

HARRINGTON, T.L., HARRINGTON, M.K. (2000) Gerontechnology: Why and How, Shaker Publishing B.V., Maastricht.

HEYWOOD, F. (2004) The health outcomes of housing adaptations, Disability and Society (19) 129-143.

HEYWOOD, F., OLDMAN, C., MEANS, R. (2002) Housing and Home in Later Life, Open University Press, Buckingdom, New York.

HOJNIK-ZUPANC, I. (1999) Independence of the elderly in the social and spatial contexts, Faculty of Social Sciences, Ljubljana.

IMRIE, R., HALL, P. (2001) Inclusive design: designing and developing accessible environment. Spon Press, New York.

IWARSSON, S., STAHL, A. (2003) Accessibility, usability and universal design positioning and definition of concepts describing personenvironment relationships, Disability and Rehabilitation, (25) 57-66.

JELENC, J., ed. (2007) Strategic Development Plan of technological platform I-TECHMED: innovative and assistive technology in medicine 2007-2013, Iskra Techno, Podnart.

JESPEN, M., LESCHKE, K. (2008) Social protection and the social reality of Europe, Benchmarking working Europe 2008, ed. M. Jesepen, ETUIREHS documentation centre, Brussels; 58-66.

JOINT IMPROVEMENT TEAM (2010) An assessment of the development of telecare in Scotland: 2006-2010, Scottish Government, Edinburgh.

KAYE, H.S., YEAGER, P., REED, M. (2008) Disparities in usage of assistive technology among people with disabilities. V: Assistive Technology, Let. 20, št. 4, str.: 194-203.

KERVINA, D., PUSTINŠEK, M., BEŠTER, J. (2007) Informacijske in komunikacijske tehnologije za e-vključenost and Praktični vidiki in možnosti e-vključenosti in dostopnosti za invalide, starejše in za osebe z manjšimi možnostmi, ed. F. Hočevar, Inštitut RS za rehabilitacijo, Ljubljana; 13-21.

KUBITSCHKE, L., CULLEN, K. (2010) ICT and ageing - European study on users, markets and technologies, Directorate General for Information Society and Media, Brussels.

LEE, S.Y, PHIPPEN, A. (2006) The state of elderly in ICT adoption at rural areas, University of Plymouth, Plymouth. 
LEVY, S., JACK, N., BRADLEY, D., MORISON, M., SWANSTON, M. (2003) Perspectives on telecare: The client view, Journal of Telemendicine and Telecare (9) 156-160.

MACE, R., HARDIE, G., PLACE, J. (1991) Toward universal design, Design intervention. Toward a more humane architecture, eds. W. Preiser, J. Vischer, E. White, Van Nostrand Reinold, New York; 155-175.

MARQUIÉ, J.C., JOURDAN-BODDAERT, L., HUET, N. (2002) Do older adults underestimate their actual computer knowledge?, Behaviour $\mathcal{E}$ Information Technology (21) 273-280.

McCREADIE, C., TINKER, A. (2005) The acceptability of assistive technology to older people, Ageing and Society (25) 91-110.

MINISTRY OF LABOUR, FAMILY AND SOCIAL AFFAIRS (2007) Strategy of care for the elderly till 2010 - Solidarity, living together and quality ageing of the population, Government of the Republic of Slovenia, Ljubljana.

MISKELLY, F.G. (2001) Assistive technology in elderly care, Age and Ageing (30) $455-458$.

MORAN, R. (1993) The electronic home: Social and spatial aspects, European Communities, Dublin.

OCEPEK, J., ZUPAN, A. (2008) Dom IRIS - an innovation in rehabilitation medicine, Jpurnal of the Metrology Institute of the Republic of Slovenia (18) 12-17.

PEČJAK, V. (1998) The third age psychology, Free Press, Ljubljana.

PECORA, F., CESTA, A. (2007) DCOP for smart homes: A case study, Computational Inelligence (23) 395-419.

PERCIVAL, J., HANSON, J. (2006) Big brother or brave new world? Telecare and its implications for older people's independence and social inclusion, Critical Social Policy (26) 888-909.

RAAPPANA, A., RAUMA, M., MELKAS, H. (2007) Impact of safety alarm systems on care personnel, Gerontechnology (6) 112-117.

REDFORD, L.J., WHITTEN, P. (1997) Access to technology: Unique challenges for people with disabilities, Generations 21, San Francisco.

REMAGNINO, P., SHAPIO, D. (2007) Artificial intelligence methodes for ambient intelligence, Computational Intelligence (23) 393-394.

RICHARDSON, M., WEAVER, C.K., ZORN, T.E. (2005) ‘Getting on': Older New Zealanders' perceptions of computing, New Media and Society (7) 219-245.

RICHARDSON, M.A. (2006) Interruption events and sensemaking processes: A narrative analysis of older people's relationships with computers, University of Waikato, Waikato.

RODRIGUEZ, M.D., FAVELA, J., PRECIADO, A., VIZCAÍNO, A. (2005) Agent-based ambient intelligence for healthcare, AI Communications - Agents Applied in Health Care (18) 201-216.

ROGERS, E. (1962) Diffusion of innovations, Free Press, London.

ROJO PEREZ, F., FERNANDEZ-MAYORALAS FERNANDEZ, G., POZO RIVERA, E., MANUEL ROJO ABUIN, J. (2001) Ageing in place: 
Predictors of the residential satisfaction of elderly, Social Indicators Research (54) 173-208.

RUDEL, D. (2007) Information and communication technologies for telecare of a patient at home, Rehabilitacija (6) 94-100.

RUDEL, D., HOJNIK, I., PREMIK. M. (1993) The strategy for the introduction of telecommunication centers to organize help at home, MKS Electronic Systems, Ljubljana.

RUDEL, D., PREMIK, M. (2000) Telecare for health of old, disabled and permanently ill people at home, Informatica Medica Slovenica (6) 111114.

SABIA, J.J. (2008) There's no place like home: A hazard model analysis of aging in place among older homeowners in the PSID, Research on Aging (30) 3-35.

SARANUMMI. N., KORHONEN, I., KIVISAARI, S., AHJOPALO, H. (2006) A framework for developing distributed ICT applications for health, distributed diagnosis and home healthcare, Conference Proceedings - 1st Transdisciplinary Conference on Distributed Diagnosis and Home Healthcare 2006 - D2H2, Arlington, 137-143.

SIXSMITH, A., SIXSMITH, J. (2000) Smart care technologies: meeting whose needs?, Journal of Telemedicine and Telecare (6) 190-192.

SPONSELEE, A., SCHOUTEN, B., BOUWHUIS, D., WILLEMS, C. (2008) Smart home technology for the elderly: Perceptions of multidisciplinary stakeholders, Communications in Computer and Information Science (11) 314-326.

Surrey Telecare. (2013). Local Telecare Services. [http://www.surreytelecare. com] (22.11.2013).

TETLEY, J., HANSON, E., CLARKE, A. (2001) Older people, telematics and care, Care services for later life: Transformations and critiques, eds. T. Warren, L. Warren, M. Nolan, Jessica Kinglsey, London; 243-258.

United Nations Department of Economic and Social Affairs. (2013). Population devison, polulation estimates and projections section. [http:// esa.un.org/unpd/wpp/unpp/panel_population.htm] (10.06.2013).

WILESA, J.L., ALLENA, R.E.S., PALMERA, A.J., HAYMANA, K.J., KEELINGB, S., KERSEA, N. (2009) Older people and their social spaces: A study of well-being and attachment to place in Aotearoa New Zealand, Social Science and Medicine (68) 664-671.

WYLDE, M., VALINS, M.S. (1996) The impact of technology, Futurecare: New directions in planning health and care environments, eds. M.S. Valins, D. Salter, John Wiley and Sons, Oxford; 5-24.

ZUPAN, A., CUGELJ, R., HOČEVAR, F. (2007) IRIS Home (Independent residing enabled by intelligent solutions), Rehabilitacija (6) 101-104. 
Alındı: 16.06.2013; Son Metin: 16.01.2014

Anahtar sözcükler: Yapılı çevre; yaşam çevresi; yardımcı teknolojiler; akıllı ev; yaşlılar.

\section{YAŞLILAR İÇIN KONUTLARDA YENİLIKKÇİ BİR YAPILI ÇEVRE Bíçìi}

Nüfusun yaşlanması karşısında, ülkelerin yaşlılara sağlayabildiği hizmetler ve kurumsal bakım konusunda maddi kapasiteleri giderek azalmaktadır. Bu nedenle yaşlılar için gerekli olan hizmetler ve evde bakım talepleri artmaktadır. Ana fikir yaşlıların evlerinde olabildiğince uzun kalmaları ve yaşlıları hedefleyen hizmetlerin ev ortamlarına taşınması olduğundan talepler anlamlıdır. Bu fikir yapılı çevreyi uygun bir şekilde uyarlanarak gerçekleştirilebilir. Bunu uygulamanın en iyi yollarından biri ise yaşlı kişilerin evlerini yenilikçi bir yaşam ortamına çevirebilecek modern teknolojilerin kullanılmasıdır. Bu çalışma, yaşlılara böyle bir destek sağlayan yaşam çevreleri hakkındadır. Bu makalede, bu desteği sağlamanın önemi ve işleyiş şekli, günümüze kadar bu yeniliğin geliştirilmesindeki çabalar ve elde edilen başarılar, yaşlıların böyle gelişmiş yaşam ortamlarında yaşamak konusundaki fikirleri temel alınarak toplumda uygulama potansiyeli tartışılmaktadır. Bulgular, uygulamada esas amacın kullanıcıların yenilikçi yapılı çevreyi anlamaları ve ona anlam yüklemeleri olduğunu göstermektedir. Ayrıca toplumda yenilikçi yapılı çevre uygulamalarının çok çabuk gelişmesinin beklenmemesi gerektiği anlaşılmaktadır. Eğer yaşlıların yaşam alanları bilinçli olarak herkes için tasarım ilkelerine göre yeniden düzenlenir, içerdikleri mimari engeller ortadan kaldırılır ve yeni evler bu engeller olmayacak biçimde tasarlanırsa, bu anlamda önemli bir adım atılmış olacaktır. Yalnız bu bile, yaşlıların evlerinde daha uzun süre kalmalarını sağlarken bu yaşam alanlarını gelecekte yardımcı teknolojiler kullanarak akıllı evlere dönüştürmekte başlangıç noktası olabilir.

BOŠTJAN KERBLER; PhD,

Received $\mathrm{PhD}$ in social geography. He is a researcher at the Urban Planning Institute of the Republic of Slovenia. His research deals with spatial planning and housing for older people and people with disabilities. He is the editor of the international scholarly journal Urbani Izziv ["Urban Challenge”]. bostjan.kerbler@uirs.si 